\title{
NPRL3 wt Allele
}

National Cancer Institute

\section{Source}

National Cancer Institute. NPRL3 wt Allele. NCI Thesaurus. Code C106287.

Human NPRL3 wild-type allele is located in the vicinity of $16 \mathrm{p} 13.3$ and is approximately 55 $\mathrm{kb}$ in length. This allele, which encodes nitrog en permease regulator 3 -like protein, has no known function. 